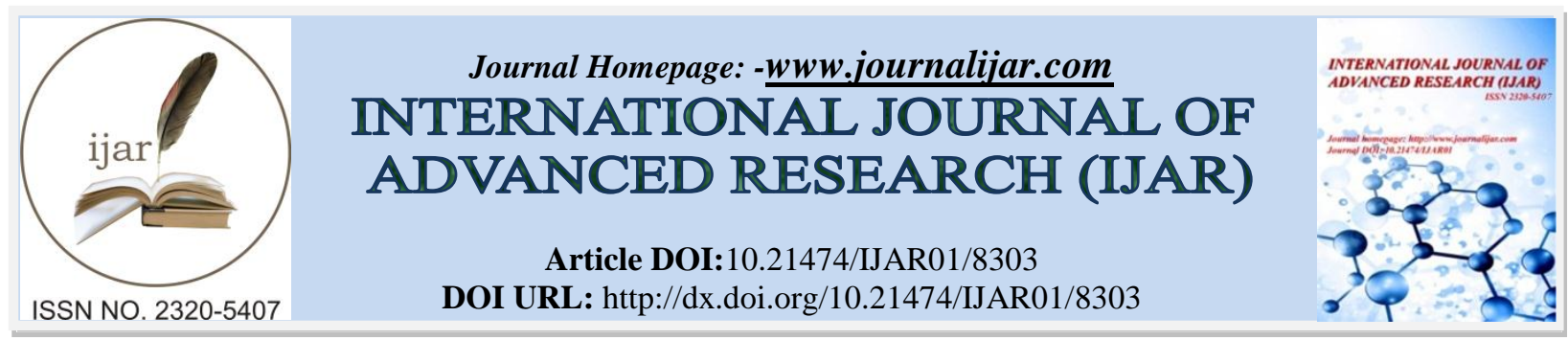

RESEARCH ARTICLE

\title{
HOW AMERICAN HIGHER EDUCATION SHIFTED FROM FREE TO BACKBREAKING TUITION ENTERPRISE?.
}

Hamidullah Bamik.

Fulbright Scholar and Graduate Student in Educational Leadership and Policy Analysis, Department of Educational Leadership and Policy Analysis, College of Education, University of Missouri-Columbia USA.

\section{Manuscript Info}

Manuscript History

Received: 01 November 2018

Final Accepted: 03 December 2018

Published: January 2019

Key words:-

American Higher Education, Tuition,

Students' Loans, Accessibility and

Affordability, American Higher

Education Credentials,

Internationalization Privatization and

Commercialization of Higher Education

Enterprise in the US .

\begin{abstract}
Due to the increase in tuition, when choosing a university to studying the US, costs are becoming a serious problem. The average cost of higher education in the US in 2016-2017 ranged from $\$ 9,700$ for public four-year institutions to $\$ 33,500$ for private four-year institutions, and this price is getting increased annually. Indeed, after World War II when the GI bill was introduced to the public for the purpose of making more accessible higher education to war veterans, the college attendance also rose rapidly. As a result of the dramatic increase in the student body at colleges and universities, the tuition in higher education was also changed. But the real change in higher education cost occurred when the value, quality, and quantity of higher education increased, and eventually, this transformation uprooted the long-lasting free tuition higher education in the United States. The findings of this paper demonstrate that the high cost of college attendance led many students out of colleges from the beginning and left hundreds and thousands of students with incomplete educational degrees. For this reason, the current paper aims to provide an answer to the question that how and why the tuition increased in higher education in the US after World War II. The article is prepared by a desk study using a variety of presently available researches, papers, and data related to students' tuition, accommodation cost, and loans.
\end{abstract}

Copy Right, IJAR, 2017. All rights reserved.

\section{Introduction:-}

In comparison to other countries in the world, studying at higher American higher education institutions is far more expensive. The average cost of higher education in the United States in 2016-2017 ranged from \$9,700 for public four-year institutions to $\$ 33,500$ for private four-year institutions, and this price is getting increased annually. Indeed, after WW II when the GI bill was introduced to the public for the purpose of making more accessible higher education to war veterans, the college attendance also rose rapidly. As a result of the dramatic increase in the student body at colleges and universities, the tuition in higher education was also changed. But the real change in higher education cost occurred when the value, quality, and quantity of higher education increased, and eventually, this transformation uprooted the long-lasting free tuition higher education in the United States (Hoxby, 1997).

This paper aims to provide an answer to the question that how and why the tuition increased in higher education in the USA after WWII. The main research question of this paper is also the title of this paper: Why and how did the

\section{Corresponding Author:-Hamidullah Bamik}

Address:-Fulbright Scholar and Graduate Student in Educational Leadership and Policy Analysis, 
tuition in higher education increase in the USA after WWII? The other questions that arise might be: what are the impacts of tuition increment on the public? What are the reasons fortuition increase in higher education? How can colleges and universities' authorities cope with tuition increase? Does tuition increase widen the gap between lowsocioeconomically marginalized students and high-socioeconomically status students? I will answer the abovementioned questions in this paper. The ensuing paragraphs highlight the major events that played a significant role in increasing colleges and universities' attendance costs after WWII, the main reasons of tuition increase, the grave consequences of tuition increment, and the possible ways for reducing the unaffordable costs of American higher education institutions.

\section{Methodology: -}

Increasing admission tuition and student loans annually in the American higher education enterprise is one of the most daunting and harrowing challenges that students are struggling with today in the US. This high cost of college attendance led many students out of colleges from the beginning and left hundreds and thousands of students with incomplete educational degrees. Given that, the present study intends to examine how and why American higher education shifted from an absolute free educational enterprise to a backbreaking tuition enterprise. For conducting this research, I have used a qualitative method and desk study. The data for the current study is collected from reliable sources such as American Think Tanks analytical reports, American higher education associations reports, peer-reviewed articles, leading national news agencies in the US, and numerous other genuine sources.

\section{Literature Review: -}

\section{A Brief Glance at the History of Higher Education Cost since WWII:-}

The beginning of the end of tuition-free started with the WWII G.I. Bill which gave vets up to $\$ 500$ to attend public or private universities. Returning of veterans at educational institutions led to overcrowding universities and colleges with many who had never been able to attend higher education before. So, as attendance rose, costs of higher education increased too (Thalin, 2013). He argues that returning of hundreds and thousands of vets forced colleges and universities to add classrooms, laboratories, dorm buildings, research labs, and staff. Likewise, society began to expect, and sometimes legally require, specific college degrees if people wanted to work in many careers.

The tuition costs only rose slightly during the '50s and '60s despite the increasing demand for college mentioned above. From the late $60 \mathrm{~s}$ and forward several cultural upheavals and alternation in state laws, the cost of higher education increased. In 1965, the administration of Johnson, the federal government started guaranteeing student loans provided by banks and non-profit lenders. Since 1960 and afterward the federal state decided to use tax to guarantee students' loans in lieu of funding the public universities, this led to a program called Federal Family Education Loan (FFEL) (Nations, 2017).

Since the Mass Higher Education Era through the 1970s, the cost of higher education started increasing more than the rate of inflation, but the income of families was also increasing so attending colleges and universities was financially affordable for the public. Likewise, during the Mass Higher Education Era, student aid program supported by the state also expanded so that students can attend both public and private universities. But unfortunately, by 1980 s the tuition of colleges and universities rose faster than the inflation rate and families' income (Cohen, A. M., \& Kisker, C. B., 2010). Cohen and Kisker (2010) articulate that after the 1980s the families' income increased by $50 \%$ while the cost of higher education increased by $90 \%$.

Between 1980 and early 1990s, the tuition in higher education increased by10 \% and between 1991-1992, it jumped to $14 \%$. But when the financial support of the federal-state decreased for students, colleges and universities also increased their tuition. For example, between 1987 and 1994 the tuition for in-state students at California University jumped from $\$ 1,500$ to more than $\$ 4,000$. In other words, in 1977 the average cost of all types institutions was $\$ 924$ but it became $\$ 3,517$ by 1993 . At public colleges and universities, the increase jumped from $\$ 479$ to $\$ 1,782$ and at private colleges and universities, the cost of attendance jumped from $\$ 2,467$ to $\$ 9,942$ (National Center for Education Statistics, 1996 cited in Cohen \& Kisker, 2016).

The rapid tuition increment forced institutions to think about the possible solution for unraveling this problem. Eventually, universities and colleges decided to start prepayment plans. This prepayment plan could help the families to pay the tuition of their progenies at the time of university entrance exam so that they can prevent from paying too much later because of annual tuition increment. For instance, the state of Missouri adopted the plan of an 
income tax deduction. This plan allowed the state of Missouri to contribute financially to the University of Missouri by collecting the income tax revenues (Manning \& Crosta, 2014).

The loss of public funding, which was concurrent with increases in tuition, led the federal government to develop federal college grants and student loans. Easy student loan financing for both private and public colleges and the competitive nature of private for-profit colleges contributed to a dangerous cycle. It allowed both public and private colleges to raise tuition continuously without fear of decreasing enrollment. This led to states cutting funding again and again. The federal government's response was to raise the student loan limits per credit hour and access to grants repeatedly. Between 1976 and 2012, the average tuition rates for college had risen 1,120\% (Langelett et al., 2015). Langelett et al. (2015) argue that this is faster and higher than any other product or service in the US, and the main problem is here that despite a huge increment in higher education cost over the past decades, students aren't receiving $1,120 \%$ better education today.

\section{The Reasons for Tuition Increment in American Higher Education:-}

In the increment of higher education cost several factors are involved such as (a) recruiting out-of-state students, (b) unlimited recruitment of international students, (c) allocating lavish and huge amount of money on campus expansion, erecting dorms and gyms, (d) tough and improper competition on academic ranks in higher education, and (e) inappropriate clamors for college and university credentials among the people. All the above issues converged and led to tuition increase over the past decades (Bastedo et al., 2016; Morphey \& Eckel 2009; Selingo, 2013). I will expound each of the above-mentioned reasons in the following paragraphs.

First, adopting the policy of recruiting out-of-state students: This policy led to exclusion of thousands of instate students. Since out-of-state students pay twice as much as their in-state counterparts, many private and public colleges and universities have increased their tuition and also the numbers of their out-of-state students (Bastedo et al., 2016).

Likewise, the policy of recruiting more international students has undermined the concept of college accessibility and affordability in higher education for domestic students because the clamor of international students for American colleges and universities' credentials has encouraged American colleges and universities to increase their tuition without considering the financial situation of American lowsocioeconomic status families. As the non-domestic students pay more than domestics students, colleges and universities are increasing the scale of their international students' recruitment at the cost of victimizing their domestic counterparts. For example, the University of Delaware in 2007 enrolled just eight Chinese students - four years later the number became 500 Chinese students (Bastedo et al., 2016).

When international students are ready to pay a huge amount of money for American colleges and universities for getting admission because of their high-profile academic credentials and academic quality, these institutions increase their annual tuition accordingly. Since domestic students cannot compete with international students financially, they either leave the idea of going to college or drop university in the second and third semester because of not having the financial capability to pay their college attendance cost (Selingo, 2013). Selingo (2013) argues that when there is a high demand for admission from outside America with good money, for sure the college and university authorities have more propensity towards recruiting international students rather than domestic students.

When international students are ready to pay too much to American colleges and universities, the institutions' authorities like to prefer them to domestic ones because they pay more, and institutions want more money. So, giving such priority to international students because of financial capability will lead to the systematic exclusion of domestic students particularly those students who cannot afford to pay even the half of that much paid by international students. For instance, in 2012, the Mount Holyoke College, a prestigious women's school in Massachusetts recruited more than 600 Chinese students that filled out its entire freshman classes, and no slot was left for domestic students (Selingo, 2013). So those American students who wanted to join Mount Holyoke College were excluded very technically and systematically.

Second, nowadays colleges and universities are allocating a huge amount of their budget on erecting gyms and dissemination of sports advertisement, recruiting high-paid salary coaches, and expensive sports equipment. It is obvious that sport is an essential pillar of the society and there is no doubt in this regard, but 
when the business of sports is overlapped with the business of education, it can lead to many financial and material changes in higher education. Since the business of sports especially football has become a kind of competition and prestige for American universities and colleges, the stakeholders and presidents of each institution are trying to invest more and more in this respect so that they can become the winner of the competition (Morphey\& Eckel, 2009). Morphey and Eckel (2009) point out that unfortunately, this victory is achieved at the expense of tuition increase and diversion of colleges and universities' attention from the main purposes of higher education institutions - public services - towards to a competition which its beneficiaries are only private and multibillionaire companies not students, professors, and admin staff.

Similarly, colleges and universities are spending too much money nowadays on constructing campuses, dining halls, dorms, and other identity centers. To cover these huge expenditures, universities and colleges have no alternative except to increase their tuition so that they can be able to balance their budget and not to encounter financial exigency. Unluckily, again the victims of these lavish expenses are students' families who are obliged to pay through their progenies' college tuition (Bastedo et al., 2016).

Third, the reduction in federal funds for colleges and universities also led to tuition increase in higher education. When colleges and universities are not receiving the federal state's funds directly anymore, they inevitably increase the cost of their academic credentials so that they can afford to supply their faculty salary, expenditures, and keep satisfied their trustees and stakeholders (Selingo, 2013).

Fourth, since having a college degree became an indisputable need for adults even if that is not needed in the job market also led to tuition increase in higher education. For example, some jobs necessarily do not require any college degree, but the people are paying too much for getting a university degree. It is true that attaining a college degree is better than not having it. In other words, having a college degree will help the adults find a better job with a good salary. But the problem is here that when universities and colleges notice that there is a high demand for a college degree, they keep increasing their tuition year by year, and students are obliged to pay too much if they intend to obtain a college degree. After graduation when these students enter the job market and cannot find a high paid job easily, they eventually start with low-paid jobs that necessarily do not require any university diploma. At that time, they understand that spending too much on obtaining university credentials was not a good choice (Morphey \& Eckel, 2009).

"I am not saying that people should stop going to colleges and universities so that the price of a college degree should not increase" (Morphey \& Eckel, 2009, p.23). Morphey and Eckel (2009) argue that those jobs which do not need any college degree, people should not spend their money on it because when colleges and universities notice that people want their products even if not needed in the bob market, they keep increasing the price of their academic credentials. This is the rule of nature and economics, when there is a high demand for a product, the price of that commodity will go up accordingly.

Fifth, the institutional ranking is another factor that provokes colleges and universities to raise their tuitions. Colleges and universities pay too much to the authorities of US News to upgrade their colleges and universities' ranks or main their superiority in the world of academia because the presidents and stakeholders of these institutions are fully aware of this issue that the more their colleges and universities are in the high-ranking category, the more they will be able to recruit international and high-income domestic students. So, when universities and colleges have high demand for applications due to their highly ranked academic programs, they can easily increase their tuition. Students, in order to have a diploma from a highly ranked university and college so that they can be more competent and privileged than their rivals in the job market, are ready to pay a huge amount of money for obtaining academic credentials from these colleges and universities (Bryan \& Whipple, 1995).

\section{The Consequences of Tuition Increase in American Higher Education:-}

The tuition increase in higher education has had grave and heavy impacts on the public and especially on the lowsocioeconomic status students. It resulted into more students' loans, widening the gap between represented and underrepresented groups in the society, increasing colleges and universities dropouts, college and university degree completion retardation, and decreasing the rate of domestic students' enrolment at colleges and universities (Anderson, Boyles, \& Rainie July 27, 2012; Bryan \& Whipple, 1995; Selingo, 2013). 
First, tuition increment not only has had grave and adverse consequences on the public but also it undermined the academic and institutional functions of the colleges and universities too. For example, Birmingham-Southern College in 2007 had spent too much on erecting new dining and gym buildings, campus expansion, and constructing new dorms for students. Birmingham-Southern College increased its tuition to cover its huge expenditures, but it did not happen as the college authorities had planned. As a result, the Birmingham-Southern College faced \$13 million deficit in its budget. To confront this tough financial challenge, the Birmingham-Southern College was obliged to lay off dozens of professors, eliminated five majors, cutting millions in expenses and dismissing dozens of custodial and admin staff (Selingo, 2013).

In 1995, the United States of America was the first in academic records among the OECD countries - with a 33 percent graduation rate. Since that time the graduation rate increased in other member countries while in the United States it decreased because of college dropouts and decreasing the affordability and accessibility of colleges and universities to most low-income families. Now the graduate rate of American young people ranked $19^{\text {th }}$ out of 29 OECD countries. In OECD countries half of their young people have obtained education their parents' level education while in the United States only 20 percent of men and 27 percent women have attained their parents' level of education (Bryan \& Whipple, 1995). So, these are the grave and bitter results of tuition increase in higher education in the United States.

Also, tuition increment by colleges and universities have effectuated income inequality and racial division among the people. Moreover, the high cost of higher education widened the gap between elites and ordinary people in society. The documents showcase that raising tuition in higher education has given this sensation to students to question the mission of higher education as a public good. For example, when a large number of Americans cannot afford to pay the cost of those highly selective and ranked colleges and universities' tuition of which academic programs fit well with their interests and professional background, they are forced to attend colleges and universities whose tuition is low even if their academic programs don't meet their expectations and don't fit their professional experiences. This situation hurts the true of the feeling of students and families regarding the mission of higher education as a public good (Selingo, 2013). Selingo (2013) holds that unaffordability and inaccessibility of highly qualified colleges and universities have skewed and disguised the concept of higher education as a public trust in the society.

Nowadays, $75 \%$ of Americans are in this belief that colleges and universities are not accessible to most people. The first and the most important reason that large numbers of Americans are not going to colleges and universities or if going but not finishing their degree is that they cannot afford to pay the tuition. American colleges and universities for decades have traded on the value of their academic credentials in the job markets, pushed up the prices and forced the families to pay the prices - that financial strategy is still unabated and even getting more and more predominant in the entire American academic campuses (Anderson, Boyles, \& Rainie July 27, 2012).

\section{Recommendations for Policy Implications: -}

As a first step to slow down the speed of tuition increase in higher education, colleges and universities must reduce their budget on athletic activities, constructing skyscraper buildings, and campus expansions. This strategy can help universities and colleges' authorities to prevent the gigantic annual increase in higher education cost. Instead, colleges and universities should invest more in providing academic sources like libraries, laboratories, scientific equipment, and conducting research because erecting skyscraper buildings and campus expansion do not have any significant impacts on the quality of learning and teaching. Through applying this strategy, colleges and universities can keep their budget normal and will not face any monetary deficit to be forced to increase their tuition (Morphey \& Eckel, 2009).

Second, some universities and colleges have a good reputation and prestige in some majors and academic programs. They must invest too much in those programs and work hard to increase the number of their applicants in those academic areas. On the contrary, in some majors and departments, they may not have a considerable number of candidates due to their low academic ranking and maybe poor academic quality. So, there is no need to have them in the list of their academic programs since they are not favoured by the students. In other words, when a major or department does not have many applicants, it indicates that there are other universities that have rigorous academic qualifications in those niches, and students are likely to choose them as their first-choice academic home. So, by removing the less-wanted academic programs, colleges and universities can decrease their workloads and increase their efficiency and effectiveness in other academic disciplines that are highly ranked (Manning \& Crosta, 2014). 
Consequently, this policy will give the chance and power to the universities and colleges' authorities to prevent from facing a financial deficit and keep their tuition affordable for all the strata of the society.

Third, decreasing the infusion of international students by colleges and universities can help them to keep balanced the scale of their domestic and international students and prevent from annual increase in higher education cost. For instance, when there is less entrance of international students to American colleges and universities, colleges and universities will be compelled to keep their tuition low and affordable in order to attract the domestic students especially from the low-income strata of the society (Selingo, 2013). Hence, applying this strategy can provide more opportunities for indigent domestic students to attend colleges and universities.

Fourth, reducing the salaries of presidents of colleges and universities and football coaches can also help higher education authorities to halt the huge annual increase in tuition. The documents indicate that the annual salary of 36 private college presidents were more than $\$ 1$ million - each in 2012. Likewise, the second high-paid job at colleges and universities is pertaining to football coaches. For example, the football coach of Texas A\&M earned $\$ 4.5$ million in 2014. If half of this amount is paid to university presidents and football coaches will suffice their families' expenditures for the entire year and even, they can to save some portions of their salary for their future lives. Usually, allocating a hugeamount of money to presidents and football coaches by colleges and universities do not add anything to students' learning effectiveness and efficiency. Hence, by decreasing the salary of college presidents and coaches, colleges and universities will not be obliged to increase the tuition for supplying the salary of high-paid jobs (Fox, 2017). For sure, making such strategies and their implementation need strong political and collective determination, but it is possible if the pro- organizations of colleges and universities' affordability and accessibility pressure on higher education authorities and states for taking such preventions (Selingo, 2013).

\section{Conclusion: -}

During conducting this research, I came to this conclusion that the excessive increment in higher education costs has raised many issues for students, parents, educational leaders, politicians, funding agencies, governments, and generally all-American citizenry. These issues can include such as (a) social frustration, (b) bolstering the gap between poor and rich strata of the society, (c) delays in degree completion, and (d) discouragement among the adults regarding academic persistence in the society.

There are many hidden facets regarding the tuition increment that this paper could not uncover; likewise, there are several questions that one can ask about the rapid rise in higher education cost. For example, who are the main beneficiaries of the tuition increase? What are the roles and impacts of privatization, corporatization, and commercialization processes on the rising cost of higher education? What are the effects of students' loans on colleges and universities recruitment policy? And many more questions that require further investigations and research.

I personally think that in the near future the problem of tuition increment will not be solved, and this trend will hover for years. Indeed, unless the public and those who think about the future of American generations, those who still embrace and laud the American dream stand against the harrowing trading on academic credentials by universities and colleges, we may not be the beholders of a sustainable and dynamic turnabout in decisions of colleges and universities' key authorities' regarding the tuition reduction.

\section{References: -}

1. Bastedo, M. N., Altbach, P. G., \& Gumport, P. J. (2016). American higher education in the twenty-first century: Social, political, and economic challenges. Baltimore, MD: John Hopkins University Press.

2. Bryan, G. A., \& Whipple, T. W. (1995). Tuition elasticity of the demand for higher education among current students: A pricing model. The journal of higher education, 66(5), 560-574.

3. Cohen, A. M., \& Kisker, C. B. (Eds.) (2010) The Shaping of American Higher Education: Emergence and Growth of the Contemporary System (2nd ed.). San Francisco, CA: Jossey-Bass.

4. Fox, E. J. (2017). The highest paid public university presidents. Retrieved from http://money.cnn.com/2015/06/07/pf/college/highest-paid-public-university-presidents/index.html

5. Langelett, G., Chang, K.-L., Ola' Akinfenwa, S., Jorgensen, N., \& Bhattarai, K. (2015). The elasticity of demand for tuition fees at an institution of higher education. Journal of Higher Education Policy \& Management, 37(1), 111-119. doi:10.1080/1360080X.2014.991536 
6. Hoxby, C. M. (1997). How the changing market structure of US higher education explains college tuition. Retrieved from http://www.nber.org/papers/w6323.pdf

7. Manning, T. M., \& Crosta, P. M. (2014). Program Costs and Student Completion. New Directions for Community Colleges, 2014(168), 41-51. doi:10.1002/cc.20119

8. Morphew, C. C. \& Eckel, A. D. (2009). Privatizing the public universities. Baltimore, Maryland: Johns Hopkins University Press.

9. Nations, J. (2017). Who Pays for Higher Education? The Politics of Legislating College Costs in the United States. In: Scholarship, University of California.

10. Anderson, J., Boyles, J. L., \& Rainie, L. (July 27, 2012). The Future of Higher Education. Retrieved from http://www.pewinternet.org/2012/07/27/the-future-of-higher-education/

11. Thelin, J. R. (2013). The Rising Costs of Higher Education: A Reference Handbook: A Reference Handbook: ABC-CLIO.

12. Selingo, J.J. (2013). College Unbounded: the future of higher education and what it means for students. Las Vegas, NV: Amazon. 